\title{
A Lot of Talk, But Little Action-The Blind Spots of Nordic Environmental Security Policy
}

\author{
Emma Hakala 1,2,*®i) Ville Lähde ${ }^{2}$, Antti Majava ${ }^{2}$, Tero Toivanen ${ }^{2}$, Tere Vadén ${ }^{2}$, \\ Paavo Järvensivu ${ }^{2}$ and Jussi T. Eronen ${ }^{2,3, *}$ \\ 1 Global Security Programme, Finnish Institute of International Affairs, 00101 Helsinki, Finland \\ 2 BIOS Research Unit, 00170 Helsinki, Finland; ville.lahde@bios.fi (V.L.); antti.majava@bios.fi (A.M.); \\ tero.toivanen@bios.fi (T.T.); tere.vaden@bios.fi (T.V.); paavo.jarvensivu@bios.fi (P.J.) \\ 3 Ecosystems and Environment Research Programme \& Helsinki Institute of Sustainability Science (HELSUS), \\ Faculty of Biological and Environmental Sciences, University of Helsinki, 00014 Helsinki, Finland \\ * Correspondence: emma.hakala@fiia.fi (E.H.); jussi.t.eronen@helsinki.fi (J.T.E.)
}

Received: 10 March 2019; Accepted: 15 April 2019; Published: 22 April 2019

check for updates

\begin{abstract}
Despite an increasing recognition that environmental change may have implications for security, there only are few policies to address the issue. This article will look at environmental security policies in Finland and Sweden and propose ways to develop more effective measures. It relies on a three-level framework that aims to enable the identification of environmental security impacts by categorising them into local, geopolitical and structural ones. The article will examine present environmental security strategies and policies in Finland and Sweden, consider their efficacy for addressing various kinds of impacts and point out approaches that are currently missing. Based on the discussion, it argues that a comprehensive policy approach is needed to tackle environmental security impacts. This requires closer coordination and interchange between sectors as well as strategic intent. In addition, further research is needed on the structural impacts of mitigating and adapting to environmental change.
\end{abstract}

Keywords: environmental security; environmental policy; societal transformation; resilience

\section{Introduction}

In recent years, environmental issues have become an increasingly established part of security and foreign policy discourse [1-3]. Climate change, in particular, features in the speeches of politicians and military officers alike as one of the major global security threats that require urgent action [4-6]. Yet the discussion has not resulted in a great deal of concrete measures and its bearing upon national polices considerably varies from one country or organisation to another $[7,8]$. From our perspective, the value of environmental security as a concept for policy practice has not gained the place or momentum it deserves.

Most of the impact and concrete discussion on environmental security has focused on climate induced conflicts $[9,10]$ and their linkages to questions such as water and food [11,12]. Other major topics have been climate impacts on critical infrastructure [13], national security [14] and increased violence [15]. These themes have played to the hands of the hard security community, giving armies and security forces the central role and initiative in the policy discourse on environmental security.

Based on our categorisation of three different kinds of security impacts of environmental change, presented in another article [16], we argue that environmental security should in fact involve a broad range of sectors. In our view, the consequences of ecological change and the efforts to mitigate and adapt to it are experienced throughout society, so environmental security policy also needs to be shaped 
by various actors. Leaving the issue only to the hard security community is less likely to produce outcomes that take into account all fields of governance affected.

Our aim in this article is to examine how different kinds of environmental security impacts-local, geopolitical and structural-have been taken into account in actual real-life policy-making. Rather than merely suggesting which issues environmental security policy should address, here we concentrate on instances where security and foreign policy explicitly has made a linkage to environmental change. In addition to reviewing the evidence, we also point out the elements that are missing from current environmental security policy. We then discuss possible reasons why environment and security have not been linked and why the field has remained a marginal one.

In the next section, we outline the present state of policies on environmental security. We focus on the role environmental security has been traditionally given, overview the topics briefly and go on to discuss how its present role makes it subordinate to traditional geopolitical and security analysis. We use the Nordic countries Finland and Sweden as examples to illustrate how the security impacts of environmental change are currently incorporated into security and foreign policy. Relying on our three-level framework of environmental security impacts [16], we illustrate what is missing from current policy and how the inclusion of the neglected parts can help policy-making on environmental security.

\section{Turning Environmental Security into Policy}

Current research suggests that despite some examples of acknowledgement at a high political level, environmental security has not been turned into policy in a systematic way $[7,8,17]$. Governance on the topic has been fragmented among a number of institutions and lacks common conceptualisations and responses $[7,18]$. This may be partly explained by the theoretical literature, which covers an extensive scope but lacks a degree of coherence, making it difficult to pinpoint specific policies. We describe the theoretical approaches in more detail in a companion article [16].

As an intrinsically transboundary issue, environmental security questions fit particularly into the work of inter-governmental bodies, although no single actor has taken the lead on the issue. The UN Security Council (UNSC) has held both formal and informal discussions on environmental issues, especially emphasising the role of climate change $[19,20]$ and natural resources [21] in conflicts. The acknowledgement has been regarded as an important signal of approval for the linkage of environment and security [22], but the UNSC has also been criticised for not taking a strong enough stance or coming up with concrete actions [23].

Some UN agencies have brought environmental security into their practical work. The UN Development Programme (UNDP) integrates the environment into its human security approach, emphasising its interconnections with other aspects of sustainable development [24]. Meanwhile, the UN Environment Programme (UNEP) has a unit for conflicts and disasters and has created concrete practices, such as post-conflict environmental assessments and early-warning systems [25]. In this sense, the work of the UN touches on both the human security and conflict approaches to environmental security, but these have not evolved into any systematic policy.

The EU has included climate change and environmental degradation in its Global Strategy from 2016, pointing out that these 'exacerbate potential conflict' [26]. It puts this strategic commitment into practice by incorporating climate security into its work on natural disasters and conflict-prevention, focusing on early-warning systems. Yet the EU has also been said to lack a systematic approach to the topic, which makes it more difficult to come up with effective, coherent measures [27].

At the state-level, responses are even more scattered. According to Brzoska's [8] comparison of the inclusion of climate change in national security and defence strategies of several countries, climate or environmental issues are often mentioned as an emerging or even a potentially significant threat, but concrete responses are rarely proposed. The United Kingdom is an exception as it has drafted measures for the defence forces to take climate change into account. Meanwhile, in the United States, the military and other actors from the traditional security sector have had a major role in promoting discussion about climate security and ways to address it in practise. Their focus has been on ensuring 
the effectiveness of defence forces in conditions of environmental change, which often leads to an emphasis on national security [28].

Some countries see environmental security as an issue of their global engagement. Germany has considered the security implications of climate change for its development cooperation [29], and also considerably contributed to the discussion on climate security at the UNSC since its non-permanent membership in 2011 [30]. Sweden, on the other hand, raised climate security high on the agenda for its membership in the UNSC, working with researchers and practitioners to find effective ways to address it through the UN system [31]. So far, however, these efforts have not produced any kind of high profile consensus on environmental security actions [32].

The lack of implementation cannot be fully put down to an inability to come up with concrete proposals for environmental security responses. Research-based analyses have suggested new practices, such as targeted risk assessments, monitoring, early-warning systems and setting up new organisational structures $[1,23,27]$. They also point out the need to integrate environmental security into existing policies and institutions across sectors. Cross-sectoral coordination and information-sharing are seen as necessary to reach a level of institutionalisation that enables environmental security approaches to actually be implemented [1,27].

Overall, the environmental security policies adopted so far have a focus on the interconnections between environment and conflict or, to a lesser degree, human security. In light of our analysis of the security impacts of environmental change [16], they therefore have potential to address local and geopolitical impacts, although no overarching approach has emerged to ensure coherence or coordination. Meanwhile, current policies almost entirely neglect the security consequences of mitigating environmental change and adapting to it. We argue that this category, which we call the structural impacts, is increasingly important as climate change and the policies to counter it advance. This aspect also highlights the need to understand the extensive, cross-sectoral implications of environmental security.

\section{Materials and Methods}

This analysis looks at environmental security policies in the case of two countries, Finland and Sweden. Often seen as 'green' countries within the EU [33], they are well placed to take environmental changes into account in policy planning. With regard to environmental security, however, neither country has been able to comprehensively recognise the full range of impacts [16]. This is likely to be reflected in policy-making as well.

Our aim is to give an overview of existing policies, and identify gaps in the current policy framework. In particular, we look at the extent to which environmental issues are taken into account in security and foreign policy, but also whether these have been implemented more practically into policy-making. Our focus is to understand the extent to which traditional security and foreign policy has been able to change and incorporate new risks associated with a changing environment. Therefore, rather than aim to identify every aspect of environmental change that could have relevance for security, we instead focus our discussion on instances where environmental issues have already been noted in security and foreign policy in Finland and Sweden.

Our focus affects our selection of materials for analysis. In order to examine the policy-relevance of environmental security, it has been necessary to focus on the key strategy and policy documents that set the foundations for the security policies of the two countries. In addition, as we are interested in policy-making that concerns security, we have only looked at strategies and policy documents that are explicitly linked to the security sector. On the basis of relevance, we have therefore focused on the following documents: Finnish Government Report on Finnish Foreign and Security Policy (2016) [34], Finnish Security Strategy for Society (2017) [35], Finnish Internal Security Strategy (2017) [36], Finnish National Risk Assessment (2018) [37], Sweden's Defence Policy 2016 to 2020 (2015) [38], A summary of risk areas and scenario analyses for the Swedish National Risk and Capability Assessment (2016) [39], and Swedish National Security Strategy (2017) [40]. In addition, in order to trace the implementation of 
the policies, we have looked at reports and documents produced by a number of state agencies [41-46], particularly ones focusing on civil preparedness and emergencies.

The analysis builds upon our observations in a companion paper [16], which looks at the extent to which environmental security impacts have been recognised in strategic assessments in Finland and Sweden. In our view, this kind of country-specific knowledge base on the security impacts of environmental change is necessary for relevant policies to emerge. In order to help identify the environmental security impacts, the companion article also provides a framework for grouping environmental security impacts into three categories: Local, geopolitical and structural impacts. The framework is shown in Table 1.

Table 1. Environmental security impacts.

\begin{tabular}{|c|c|c|c|}
\hline \multicolumn{4}{|l|}{ Local Impacts } \\
\hline Possible impacts & Geographic scope & Time frame & Scale \\
\hline $\begin{array}{l}\text { Storms, floods, droughts, heat waves and other } \\
\text { extreme weather events }\end{array}$ & Local, regional & $\begin{array}{l}\text { Short to long } \\
\text { term }\end{array}$ & $\begin{array}{l}\text { Sectoral, } \\
\text { cross-sectoral }\end{array}$ \\
\hline \multicolumn{4}{|l|}{ Geopolitical Impacts } \\
\hline \multirow{2}{*}{$\begin{array}{l}\text { Possible impacts } \\
\text { Conflict, migration, food shortages, disruptions in } \\
\text { energy production, disruptions in resource flows }\end{array}$} & Geographic scope & \multirow{2}{*}{$\begin{array}{l}\text { Time frame } \\
\text { Short to long } \\
\text { term }\end{array}$} & Scale \\
\hline & Regional, global & & Cross-sectoral \\
\hline \multicolumn{4}{|l|}{ Structural Impacts } \\
\hline \multirow{2}{*}{$\begin{array}{l}\text { Possible impacts } \\
\text { Systemic shock in energy production patterns, failure } \\
\text { of economic production system, erosion of } \\
\text { democratic governance }\end{array}$} & Geographic scope & Time frame & Scale \\
\hline & $\begin{array}{l}\text { Local, regional, } \\
\text { global }\end{array}$ & Long term & System-level \\
\hline
\end{tabular}

Based on our analysis of Finland and Sweden, local impacts are currently recognised extensively in official state-commissioned assessments, and a knowledge base exists on the potential consequences on humans and the society. Geopolitical impacts have been recognised to some extent but there is very little analysis and a low level of understanding of the interactions through which they emerge. Meanwhile, structural impacts have largely been neglected. The extent of the societal transformations needed to mitigate climate change is generally not taken into account as a factor influencing security. In other words, beyond local impacts, there are significant gaps in environmental security knowledge in both Finland and Sweden.

In this article, we utilise the results presented above to structure our analysis. For each category of impacts, we look at the issues that have been raised as potential concerns in the assessment reports, and examine whether these have been addressed in policy documents. Through this discussion, we trace the extent to which strategic analysis has been turned into policy so far. Furthermore, we examine whether any of the issues we have found to be neglected in the assessments are in any way included in the policies.

The framework shows that due to the diversity of impacts, environmental security policy cannot be based on a single, uniform policy. The actions needed to address storm damage and systemic change in energy production, for instance, are very different. Yet it is necessary to also acknowledge that the impacts are inter-connected and sometimes overlapping. Environmental security can provide this overarching approach, implemented through a variety of policies.

\section{Results: Environmental Security Policies in Finland and Sweden}

\subsection{Policies for Local Environmental Security Impacts in Finland and Sweden}

In the Finnish and Swedish assessments of local environmental security impacts, it has been pointed out that changes like increased precipitation, potential flooding, as well as rising sea levels 
and temperatures will have various kinds of consequences on the society. In particular, affected sectors include transportation; water management; health; forestry, agriculture and fishery; built infrastructure and energy [16].

Both Finnish and Swedish security strategies take note of such local impacts, but there are differences between their approaches. The main Finnish policy document focuses almost entirely on impacts that originate outside Finland [34], as does the strategy for internal security [36]. Instead, Finland deals with local impacts in its Security Strategy for Society [35], which outlines the implementation of security policy at the local and societal level. Likewise, local environmental impacts are included in the latest National Risk Assessment [37]. In the Swedish Security strategy, on the other hand, climate change is listed among the main threats facing the country, pointing out that it "impacts security in Sweden both directly and indirectly" [40]. The description of direct impacts correlates approximately with local impacts in our framework, as they refer to concrete impacts, like flooding and heavy rain, and their consequences to critical services maintaining the society. Meanwhile, Swedish defence policy only mentions climate in terms of the need of the Swedish forces to be able to operate in local conditions [38].

For Finland, the Security Strategy for Society particularly points out environmental accidents, such as oil spills at sea [35]. However, it also includes a section on the "[d]etection and monitoring of changes taking place in the environment, adapting to the changes and combating the threats arising from them". It points out that "environmental threats may cause significant property and environmental damage", although it does not explain in more detail what the threats could be like.

The Swedish strategy document points out that "[a] change in climate has implications for many key services in society", such as "physical planning, buildings, communications and transport infrastructure, technical supply systems and, of course, agriculture, hunting and fishing". In particular, it emphasises the risk of flooding in various areas of the country [40]. In addition, the analysis made for the National Risk and Capability Assessment takes into account local environmental impacts and notes that climate change is likely to aggravate them. As concrete impacts it also especially mentions flooding, as well as heat waves [39].

Both countries explicate some policy measures to tackle environmental or climate impacts. The Finnish security strategy for the society relies entirely on environmental monitoring and goes on to assign responsibilities for it between several authorities, namely environmental and municipal ones, that also coordinate their work among one another [35]. Meanwhile, the Swedish strategy calls for "reducing vulnerabilities and leveraging opportunities", for example, by developing a strategy to strengthen and coordinate climate adaptation [40].

Both countries have also developed mechanisms for managing local environmental impacts, concentrating on regional and municipal authorities. Finland, for instance, has a natural disaster warning system LUOVA (Luonnononnettomuuksien varoitusjärjestelmä), which works as an information channel between relevant authorities [41]. In Sweden, activities on environmental risks are coordinated through a Working group for environmental accidents [42] and a Network for climate adaptation [43].

Yet despite the existence of such administrative structures, implementation is held back at the level of individual organisations. According to a recent study on the management of climate impacts, most municipalities in Finland do not follow climate risks systematically. They are hindered mainly by a lack of resources, but municipal actors also find it difficult to fit climate-related knowledge into local decision-making processes [44]. Similarly, inadequate resources and coordination hinder Swedish municipalities from applying effective climate adaptation measures [47].

Overall, there is a clear strategic engagement on local environmental impacts in both Finland and Sweden, and some measures have been taken to address them in policy. These also, to some extent, build upon the recognition of local impacts in strategic assessments, as many of the same issues are mentioned also at the policy level. The status of the recognition of impacts and policy responses is depicted in Table 2 below. 
Table 2. Policy framework for local environmental security impacts in Finland and Sweden.

\begin{tabular}{|c|c|c|c|}
\hline & $\begin{array}{c}\text { Impacts Recognised in } \\
\text { Assessments }\end{array}$ & $\begin{array}{l}\text { Impacts Recognised in } \\
\text { Policies/Strategies }\end{array}$ & $\begin{array}{l}\text { Policy Measures } \\
\text { Adopted }\end{array}$ \\
\hline Finland & $\begin{array}{l}\text { Precipitation, flooding, } \\
\text { temperature rise, disruptions in } \\
\text { transportation, water } \\
\text { management, health, forestry, } \\
\text { agriculture and fishery, } \\
\text { infrastructure, energy }\end{array}$ & $\begin{array}{l}\text { Environmental accidents, } \\
\text { environmental change }\end{array}$ & $\begin{array}{l}\text { Natural disaster warning } \\
\text { system; cross-sectoral } \\
\text { coordination }\end{array}$ \\
\hline Sweden & $\begin{array}{l}\text { Precipitation, flooding, heat } \\
\text { waves, disruptions in } \\
\text { transportation, water } \\
\text { management, health, areal } \\
\text { livelihoods, infrastructure, energy }\end{array}$ & $\begin{array}{l}\text { Flooding, sea level rise, } \\
\text { heat waves }\end{array}$ & $\begin{array}{l}\text { Working group for } \\
\text { environmental accidents; } \\
\text { Network for climate } \\
\text { adaptation }\end{array}$ \\
\hline
\end{tabular}

The framework for environmental security policy thus exists, but its implementation is still primarily left to individual actors that are often restricted by a lack of resources and leverage. This also suggests a deeper predicament about environmental security policy: Due to its cross-sectoral character, its implementation ultimately relies on the coordination of individual actors in a range of different fields, often in addition to their actual work. Coordination, support and especially additional resources are therefore necessary to at least pave the way for the applicability of environmental security.

\subsection{Policies for Geopolitical Environmental Security Impacts in Finland and Sweden}

Finland and Sweden have to some extent assessed geopolitical environmental security impacts, with similar results. Finland has highlighted impacts on economic production, energy, transport, business and finance, migration, health, biodiversity and development cooperation. In the Swedish case, particular focus has been given to migration, livelihoods, food security, transport and energy. The potential dynamics of these changes are not explicated in more detail, however, and the impacts are expected to remain relatively small. In our analysis, we argue that the assessments may have neglected the full scope of consequences that a 1.5 or $2{ }^{\circ} \mathrm{C}$ rise in average temperature would have [16].

The Finnish foreign and security policy paper mentions environmental threats and climate change among rising global risks that require international responses. Sustainable development, specifically in terms of the UN Agenda 2030, is considered as a key "set of goals for dealing with many global threats and challenges", also including the impacts of climate change. Climate policy is also mentioned as one of the components of dealing with the "root causes of migration". In addition, it is mentioned as a central topic in Arctic cooperation [34]. Similar goals are echoed in the strategy for internal security, which lists the 'crisis of sustainability' among the global megatrends that influence Finland. It particularly points out climate-related migration and the pressures that this can cause to Europe [36].

Apart from international cooperation and sustainable development policy, however, the Finnish security policy does not suggest clear measures to address geopolitical environmental impacts [34]. According to the internal security strategy, the influence of ecological change will not be significant during the planning period (which is not explicitly stated, but its objectives are to be achieved by 2025), but it points out that solutions for sustainable development are necessary. In particular, it stresses that Europe should prepare for increased migration, but does not clarify the measures that should be taken to this effect [36].

The Swedish Security Strategy argues that geopolitical impacts of climate change threaten Sweden as much as local ones [40]. It points out several global consequences, specifically the increased risk of conflict, poverty and lack of food or water. It also notes that the combination of these factors may result "in people being forced to flee". However, it does not clarify how exactly these influence Sweden. Yet in terms of measures to be taken, the Swedish strategy strongly emphasises the role of international cooperation. Similarly to Finland, it mentions the Agenda 2030 but also notes that "Sweden 
will continue its efforts to ensure that climate and security are high on the agenda in international organisations, particularly the UN and the EU". In addition, it suggests that strengthened "cooperation between development assistance and humanitarian aid could enable the risks and consequences of natural disasters to be reduced."

With regard to international cooperation on environmental security, Sweden has followed through substantially, especially when it comes to climate change. The link between climate and security featured prominently on the programme of its rotating membership in the UN Security Council [48], and the country chaired a debate on climate-related security risks in the UNSC in July 2018 [49]. Climate security was described as a priority for the government that held office from 2014 to 2019 [48]. Accordingly, Sweden has supported research on climate security, for example, by establishing the Stockholm Climate Security Hub, which promotes policy-making on climate security by producing up-to-date knowledge on climate risks and their prevention. In more concrete terms, the initiative has proposed creating "an institutional home" for climate security within the UN framework to coordinate and advance exchange of information on the topic [50].

Finland, on the other hand, has not put such an international emphasis on the issue [51]. The environment has been linked to security policy as a part of Finnish peace-building activities especially during the 2000s, as the country significantly contributed to funding international bodies such as the Environment and Security Initiative as well as the work of UNEP on conflicts and disasters [52]. This work, however, does not tie into a more comprehensive discussion of the security impacts of environmental change.

Instead, Finland relies heavily on its policy of security of supply, which aims to ensure the continuity of the functions or the society, such as economy, national defence and livelihoods, during major crises. As the security of supply perspective has increasingly come to emphasise inter-dependency and Finnish reliance on global resource flows [53], it seems ideal for integrating an assessment of the geopolitical impacts of environmental change. In fact, the recently updated security of supply scenarios, leading up to 2030, quite comprehensively take into account the consequences of both severe and moderate environmental change [45].

So far, however, this perspective has not featured prominently in policy-making on security of supply. The latest Government decision on the objectives of security of supply from 2018, for instance, only remarks that climate change mitigation and adaptation are taken into account unless the security of supply requires otherwise [46]. This formulation suggests that climate change is considered as something that can be taken into account if it suits other objectives, not as a critical factor of its own. In this sense, the gap between risk recognition and policy implementation is even wider on geopolitical impacts than local ones, as risk assessments do exist, but the policy framework is still largely missing.

Sweden, on the other hand, does not have a similar supply security approach. The country has instead chosen to consider geopolitical environmental security impacts as a matter of global responsibility. Certainly, the international approach is by no means inconsistent with national interest, as it may contribute to preventing environmental risks at the global scale. It can be argued that Sweden aims to address the root causes of environmental security impacts, whereas the Finnish model is more attuned to treating the symptoms. From the point of view of comprehensive environmental security policy, the two approaches should be implemented simultaneously.

Table 3 outlines the policy frameworks on geopolitical environmental security impacts for Finland and Sweden. It shows that the impacts pointed out in strategic assessments have only partially been included into foreign and security policies. In terms of implementation, there is a clear difference between Finland and Sweden. While Finland does not have specific measures either at the domestic or international level to address any of the impacts mentioned in the policy documents, Sweden has actively engaged in or initiated policy-making internationally. However, even in the Swedish case an explicit link seems to be missing between the potential impacts for Sweden and international diplomatic initiatives. It can be argued that there still is a need for more detailed analysis of geopolitical impacts and the measures to address them from a national point of view. 
Table 3. Policy framework for geopolitical environmental security impacts in Finland and Sweden.

\begin{tabular}{|c|c|c|c|}
\hline & $\begin{array}{c}\text { Impacts Recognised in } \\
\text { Assessments }\end{array}$ & $\begin{array}{l}\text { Impacts Recognised in } \\
\text { Policies/Strategies }\end{array}$ & Policy Measures Adopted \\
\hline Finland & $\begin{array}{l}\text { Economic production, energy, } \\
\text { transport, migration, health, } \\
\text { biodiversity, development } \\
\text { cooperation }\end{array}$ & $\begin{array}{c}\text { Sustainable } \\
\text { development, migration, } \\
\text { the Arctic region, } \\
\text { security of supply }\end{array}$ & $\begin{array}{l}\text { Potential for inclusion in security } \\
\text { of supply policy (domestic); } \\
\text { partially included in } \\
\text { peace-building (international) }\end{array}$ \\
\hline Sweden & $\begin{array}{l}\text { Migration, livelihoods, food } \\
\text { security, transport, energy }\end{array}$ & $\begin{array}{l}\text { Global risks of conflict, } \\
\text { poverty, lack of food or } \\
\text { water, migration }\end{array}$ & $\begin{array}{l}\text { Engagement at UN Security } \\
\text { Council, Climate Security Hub, } \\
\text { Proposal for an institutional home } \\
\text { for climate security at the UN }\end{array}$ \\
\hline
\end{tabular}

\subsection{Policies for Structural Environmental Security Impacts in Finland and Sweden}

Our analysis in another article shows that the structural impacts of environmental change is the category that has been recognised the least in Finnish and Swedish research and risk assessments [16]. The mitigation and adaptation to climate change appear to generally not be considered as the kind of policy imperatives that would have consequences of their own. Both countries do mention that the restructuring of the energy sector will have some influence on their security and foreign policy. However, they both appear to emphasise potential positive impacts-Finland in terms of increasing energy independence and Sweden with regard to opportunities for renewable energy production.

Finnish security strategy documents only mention mitigation as a way to prevent the worst consequences of climate change and adaptation as a necessity to diminish its impacts. They do not go further into discussing the scope of the measures that are needed or their potential impacts on society [34]. Meanwhile, the Finnish security of supply scenarios do factor in consequences of both strict and negligent climate mitigation policies and show how these may contribute to different outcomes [45]. The analysis does not go very deep into detail or take into account a particularly wide range of factors, but it indicates a recognition of the dynamics of environmental security impacts.

In practice, however, the appearance of climate policy in the scenarios has limited relevance. The issue is not reflected in any way in the Government decision on security of supply, which has been updated after the publication of the scenarios [46]. Likewise, it has not been picked up in the most recent National Risk Assessment. The document does point out that climate policies create insecurity on finance markets, causing new risks on holdings like oil reserves and real estate [37]. However, the strictly economic focus ends up neglecting the full scale of societal and geopolitical impacts that climate policy may have.

Similarly to the case in Finland, Swedish security strategies make no mention of security impacts of mitigation or adaptation [40]. In addition, Sweden has so far not explicitly integrated the impacts of adaptation impacts into its international climate security policies $[38,48]$. To some extent, this is consistent with the Swedish agenda, which prioritises efforts to address geopolitical effects like livelihoods, migration and conflict in the global context of international organisations. This focus may have outweighed a more domestically oriented perspective, where the impacts of climate mitigation and adaptation to Sweden might have been more apparent. However, it is also symptomatic of the way in which the international discussion on environmental security continues to largely overlook the structural impacts.

Beyond the energy sector, structural environmental security impacts are not even mentioned. The impacts of mitigation and adaptation policies on food or water security or natural resource use are not included as issues of security and foreign policy. Importantly, however, this is not to claim that Finland or Sweden would not have considered food, agriculture, water and other issues in their climate adaptation policies. Our argument is that the links are not made explicit between these issues and security policy, thereby neglecting their potential influence on it. 
The policy framework of structural environmental security impacts in Finland and Sweden is depicted in Table 4. It shows that the entire category of impacts still primarily remains outside policy-making. This can, to a great extent, be explained by the lack of recognition and knowledge of the structural dynamics even at the level of research and assessment.

Table 4. Policy framework for structural environmental security impacts in Finland and Sweden.

\begin{tabular}{|c|c|c|c|}
\hline & $\begin{array}{l}\text { Impacts Recognised in } \\
\text { Assessments }\end{array}$ & $\begin{array}{l}\text { Impacts Recognised in } \\
\text { Policies/Strategies }\end{array}$ & $\begin{array}{c}\text { Policy Measures } \\
\text { Adopted }\end{array}$ \\
\hline Finland & Energy security & $\begin{array}{c}\text { Climate change mitigation and } \\
\text { adaptation }\end{array}$ & None \\
\hline Sweden & Energy security & $\begin{array}{c}\text { Climate change mitigation and } \\
\text { adaptation }\end{array}$ & None \\
\hline
\end{tabular}

With fairly ambitious environmental policies overall and a relatively low vulnerability to local impacts, Finland and Sweden would seem to have both an interest and the resources for identifying other kinds of environmental impacts. The lack of policies for structural impacts in these countries can therefore be seen as indicative of a wider shortcoming in policy-making in global terms. An international-level discussion about the consequences of effective climate policy is yet to be had. At least so far, it does not seem as if either Finland or Sweden were likely to initiate it.

\section{Discussion}

Our analysis shows that the policy framework on environmental security in both Finland and Sweden remains fragmentary. In particular, there is no evidence of a comprehensive approach that would allow the recognition of environmental security impacts on multiple sectors and levels. As Table 5 suggests, both countries have some policies in place while others are entirely missing. However, there also are significant differences between their approaches.

Table 5. Policy framework for environmental security in Finland and Sweden.

\begin{tabular}{cccc}
\hline & \multicolumn{3}{c}{ Policy Framework in Place } \\
\cline { 2 - 4 } & Local & Geopolitical & Structural \\
\hline Finland & Extensive & Weak & None \\
Sweden & Extensive & Average & None \\
\hline
\end{tabular}

Both Finland and Sweden have an extensive set of policies and tools for countering local environmental security impacts. This is consistent with the findings of our companion article [16], which shows that several assessments have been carried out that give a fairly comprehensive background knowledge of the local impacts. However, our analysis in this article shows that there are still problems in the implementation of the policies, as this is often left to individual actors without additional resources.

The biggest differences between the countries are revealed with regard to geopolitical impacts. Sweden has an ambitious international policy especially on climate security and has gained a position as one of the leading countries maintaining the topic at the UN Security Council. However, the entirely international perspective may end up underestimating potential geopolitical impacts on Sweden itself. Finland, on the other hand, has not taken an active role in the international environmental security discussion. Its security of supply policy would provide a convenient model for integrating environmental issues into a national security policy, but so far this opportunity has only been used to a very limited extent.

Both Finland and Sweden are on equally uncharted territory when it comes to policies for structural impacts. This is by no means exceptional in global terms, as the ramifications of decarbonisation are 
only starting to be understood even in research. The Finnish and Swedish cases suggest that in practice, the recognition of the structural impacts of climate policy is virtually non-existent.

However, structural impacts are becoming increasingly essential to address also in policy as climate change advances and the actions to mitigate it will need to expand. For instance, the planned ban on coal in energy use by 2029 in Finland, would initiate a structural change in the energy sector, both in terms of electricity and heat provisioning. The National Emergency Supply Agency as well as several energy producers have in their official statements on the proposed legislation pointed out that the change would have effects on security of supply that should be better taken into account in the legislation [54]. The structural perspective to environmental security thus emphasises the role of climate policy as a fundamental part of both global and domestic policy-making. It also helps to point out that the changes following from this shift will be of such a scale that they will also influence security and geopolitics.

The issue of structural impacts is also connected to the lack of a comprehensive approach to environmental security. The analysis shows that both Finland and Sweden treat different kinds of environmental security impacts separately and with policies that are detached from one another. Although it is clear that local and geopolitical impacts, for instance, require different responses, they still share the similar underlying root causes that are linked to environmental change. It is necessary to perceive the range of different but interconnected impacts in order to understand the extent of their potential consequences on the society and to come up with policies that can adequately address them.

\section{Conclusions}

In our analysis, we have shown that there are considerable gaps in the capacities of Finnish and Swedish security and foreign policies to address environmental security impacts. This particularly concerns geopolitical and structural impacts. We further argue that a comprehensive policy approach on environmental security is necessary to thoroughly take into account the kind of complex and multi-sectoral impacts that may result from environmental change.

On the basis of these observations, we make the following recommendations for policy-making.

- Further inter-disciplinary research is needed on the geopolitical and structural environmental security impacts. The current level of knowledge is inadequate to guide well-grounded policy-making. In addition to the kind of country-specific assessments already carried out in Finland and Sweden, there is still a need for basic research to develop methodologies to understand the security consequences of global power relations and resource flows or of adaptation and mitigation. Inter-disciplinarity, also between natural and social sciences, should be encouraged in order to consider the geopolitical and structural impacts of different IPCC scenarios, for instance.

- Coordination and exchange of information between researchers and policy-makers on environmental security issues. Our analysis has shown that in the case of all environmental security impacts, policy implementation often remains inadequate. A closer interchange between researchers and policy-makers or practitioners can help to raise awareness on the potential consequences and the need for effective policy responses. For researchers, on the other hand, it gives access to invaluable information and insight from the practitioners.

- Integration of environmental change and its mitigation into risk assessments and scenario-building on various sectors. It is becoming increasingly clear that both environmental changes and actions to mitigate and adapt to them will be significant. Therefore, any risk assessments or future scenario work has to reflect this and take them into account as factors. This also concerns sectors like foreign policy and security that are not traditionally considered to be linked to the environment.

- Establishment of a comprehensive environmental security approach through a strategy or action plan. Due to the multi-sectoral character of environmental security impacts as well as the relative novelty of the concept itself, it is necessary to spell out its implications to the various 
actors involved. A strategy or action plan will be useful here as a point of reference to direct and coordinate work across sectors.

Author Contributions: Conceptualization, E.H., V.L., A.M., T.T., T.V., P.J. and J.T.E.; funding acquisition, E.H., P.J. and J.T.E.; methodology, E.H., V.L., A.M. and J.T.E.; writing—original draft, E.H., V.L., A.M., T.T., T.V., P.J. and J.T.E.; writing—review and editing, E.H., V.L., A.M., T.T., T.V., P.J. and J.T.E.

Funding: This research was funded by the Kone Foundation, the Tiina and Antti Herlin Foundation and the Strategic Research Council at the Academy of Finland (312623/312663).

Acknowledgments: The authors would like to thank three anonymous reviewers for their helpful comments on the manuscript.

Conflicts of Interest: The authors declare no conflict of interest. The funders had no role in the design of the study; in the collection, analyses, or interpretation of data; in the writing of the manuscript, or in the decision to publish the results.

\section{References}

1. Fetzek, S.; van Schaik, L. Europe's Responsibility to Prepare: Managing Climate Security Risks in a Changing World; Center for Climate and Security, Clingendael \& Planetary Security Initiative, 2018. Available online: https:/climateandsecurity.files.wordpress.com/2018/06/europes-responsibility-to-prepare_ managing-climate-security-risks-in-a-changing-world_2018_6.pdf (accessed on 26 August 2018).

2. Werrel, C.; Femia, F. Epicenters of Climate and Security: The New Geostrategic Landscape of the Anthropocene; Center for Climate and Security, 2017. Available online: https://climateandsecurity.files.wordpress.com/2017/ 06/epicenters-of-climate-and-security_the-new-geostrategic-landscape-of-the-anthropocene_2017_06_091. pdf (accessed on 25 February 2019).

3. Federal Ministry of Defence. White Paper on German Security Policy and the Future of the Bundeswehr; Federal Ministry of Defence: Berlin, Germany, 2016. Available online: https:/www.bundeswehr.de/resource/ resource/MzEzNTM4MmUzMzMyMmUzMTM1MzMyZTM2MzIzMDMwMzAzMDMwMzAzMDY5N zE3MzM1Njc2NDYyMzMyMDIwMjAyMDIw/2016\%20White\%20Paper.pdf (accessed on 26 August 2018).

4. European External Action Service. Climate, Peace and Security: The Time for Action; European External Action Service: Brussels, Belgium, 2018; Available online: https://eeas.europa.eu/headquarters/headquartershomepage/47165/climate-peace-and-security-time-action_en (accessed on 4 September 2018).

5. Bryan, J. Climate Change as a Threat Multiplier. New Atlanticist. 16 November 2017. Available online: http://www.atlanticcouncil.org/blogs/new-atlanticist/climate-change-as-a-threat-multiplier (accessed on 4 September 2018).

6. Banusiewicz, J.D. Hagel to Address 'Threat Multiplier' of Climate Change; DoD News, US Department of Defence, 13 October 2014. Available online: https://dod.defense.gov/News/Article/Article/603440/ (accessed on 4 September 2018).

7. Dellmuth, L.M.; Gustafsson, M.T.; Bremberg, N.; Mobjörk, M. Intergovernmental organizations and climate security: Advancing the research agenda. Wiley Interdiscip. Rev. Clim. Chang. 2018, 9, 496-509. [CrossRef]

8. Brzoska, M. Climate change as a driver of security policy. In Climate Change, Human Security and Violent Conflict; Scheffran, J., Brzoska, M., Brauch, H.G., Link, P.M., Schilling, J., Eds.; Springer: Berlin/Heidelberg, Germany, 2012; pp. 165-184. [CrossRef]

9. Barnett, J.; Adger, W.N. Climate change, human security and violent conflict. Political Geogr. 2007, 26, 639-655. [CrossRef]

10. Hsiang, S.M.; Burke, M.; Miguel, E. Quantifying the influence of climate on human conflict. Science 2013, 341, 1235367. [CrossRef] [PubMed]

11. Clingendael. Water, Climate and Conflict: Security Risks on the Increase? Briefing Note. 18 May 2017. Available online: https://www.clingendael.org/publication/water-climate-and-conflict-security-risksincrease (accessed on 6 February 2019).

12. Tir, J.; Stinnett, D.M. Weathering climate change: Can institutions mitigate international water conflict? J. Peace Res. 2012, 49, 211-225. [CrossRef]

13. Gemenne, F.; Barnett, J.; Adger, W.N.; Dabelko, G.D. Climate and security: Evidence, emerging risks, and a new agenda. Clim. Chang. 2014, 123, 1-9. [CrossRef] 
14. Campbell, K.M.; Weitz, R.; Gulledge, J.; McNeill, J.R.; Podesta, J.; Ogden, P.; Fuerth, L.; Woolsey, R.J.; Lennon, A.T.; Smith, J. The Age of Consequences: The Foreign Policy and National Security Implications of Global Climate Change; Center for Strategic and International Studies: Washington, DC, USA; Center for a New American Security: Washington, DC, USA, 2007.

15. Levy, B.S.; Sidel, V.W.; Patz, J.A. Climate change and collective violence. Annu. Rev. Public Health 2017, 38, 241-257. [CrossRef] [PubMed]

16. Hakala, E.; Lähde, V.; Majava, A.; Toivanen, T.; Vadén, T.; Järvensivu, P.; Eronen, J.T. Northern Warning Lights: Ambiguities of environmental security in Finland and Sweden. Sustainability 2019, 18, 2228. [CrossRef]

17. Floyd, R. Global climate security governance: A case of institutional and ideational fragmentation. Confl. Secur. Dev. 2015, 15, 119-146. [CrossRef]

18. Koff, H. Reconciling competing globalizations through regionalisms? Environmental security in the framework of expanding security norms and narrowing security policies. Globalizations 2016, 13, 664-682. [CrossRef]

19. UN Security Council. UN Security Council Resolution 2349 (2017). Adopted 31 March 2017. Available online: https://digitallibrary.un.org/record/1298484?ln=en (accessed on 28 May 2018).

20. UN Security Council. UN Security Council Resolution 2408 (2018). Adopted 27 March 2018. Available online: http://unscr.com/files/2018/02408.pdf (accessed on 28 May 2018).

21. UN Security Council. States Must Transform Natural Resources from Driver of Conflict into Development Tool to Foster Peace, Cooperation, Secretary-General Tells Security Council. Press Release. 16 October 2018. Available online: https://www.un.org/press/en/2018/sc13540.doc.htm (accessed on 19 October 2018).

22. Scott, S.V. Implications of climate change for the UN Security Council: Mapping the range of potential policy responses. Int. Aff. 2015, 91, 1317-1333. [CrossRef]

23. Born, C. A Resolution for a Peaceful Climate: Opportunities for the UN Security Council; Policy Brief; SIPRI: Solna, Sweden, 2017; Available online: https://www.sipri.org/sites/default/files/Resolution-for-peaceful-climate.pdf (accessed on 25 May 2018).

24. Elliott, L. Human security/environmental security. Contemp. Politics 2015, 21, 11-24. [CrossRef]

25. UNEP. Environment and Security: A Global Agenda for UNEP. In Proceedings of the Twenty-Third Session of the Governing Council/Global Ministerial Environment Forum Nairobi, Nairobi, Kenya, 21-25 February 2005.

26. European Union. Shared Vision, Common Action: A Stronger Europe. A Global Strategy for the European Union's Foreign and Security Policy. 2016. Available online: https:/eeas.europa.eu/archives/docs/top_stories/ pdf/eugs_review_web.pdf (accessed on 7 February 2018).

27. Mobjörk, M.; Gustafsson, M.-T.; Sonnsjö, H.; van Baalen, S.; Dellmuth, L.M.; Bremberg, N. Climate-Related Security Risks: Towards an Integrated Approach. SIPRI, Stockholm 2016. Available online: https: //www.sipri.org/sites/default/files/Climate-related-security-risks.pdf (accessed on 25 May 2018).

28. Briggs, C.M. Climate security, risk assessment and military planning. Int. Aff. 2012, 88, 1049-1064. [CrossRef]

29. GTZ. Climate Change and Security-Challenges for German Development Cooperation. Deutsche Gesellschaft für Technische Zusammenarbeit (GTZ), 2008. Available online: https://www.preventionweb.net/ files/8023_enclimatesecurity1.pdf (accessed on 18 October 2018).

30. Dröge, S. Climate and Security Revisited. SWP Comment No 34, SWP 2018. Available online: https://www. swp-berlin.org/fileadmin/contents/products/comments/2018C34_dge.pdf (accessed on 18 October 2018).

31. Government Offices of Sweden. Sweden Launches New Research Collaboration for Climate and Security. Press Release; 30 August 2018. Available online: https://www.government.se/press-releases/2018/08/swedenlaunches-new-research-collaboration-for-climate-and-security/ (accessed on 18 October 2018).

32. Vivekananda, J.; Shiloh, F.; Mobjörk, M.; Sawas, A.; Wolfmaier, S. Action on Climate and Security Risks: Review of Progress 2017. Clingendael. 6 December 2017. Available online: https://www.sipri.org/sites/ default/files/2017-12/action-on-climate-and-security-risks.pdf.pagespeed.ce_.d9-k471n1.pdf (accessed on 22 October 2018).

33. Andersen, M.S.; Liefferink, D. Strategies of the 'Green' Member States in EU Environmental Policy-making. In Environmental Policy in the EU, 2nd ed.; Jordan, A., Ed.; Routledge: Abington, UK, 2012; pp. 67-84. [CrossRef]

34. Prime Minister's Office. Government Report on Finnish Foreign and Security Policy; Government Report; Prime Minister's Office: New Delhi, India, 2016. Available online: https://valtioneuvosto.fi/documents/10616/ 1986338/VNKJ092016+en.pdf/b33c3703-29f4-4cce-a910-b05e32b676b9 (accessed on 11 February 2018). 
35. Prime Minister's Office. Security Strategy for Society. Government Resolution; 2 November 2017. Available online: https://turvallisuuskomitea.fi/wp-content/uploads/2018/04/YTS_2017_english.pdf (accessed on 9 June 2018).

36. Ministry of Interior of Finland. Hyvä elämä-Turvallinen arki. Valtioneuvoston Periaatepäätös Sisäisen Turvallisuuden Strategiasta 5.10.2017. The Internal Security Strategy. 2017. Available online: https: //intermin.fi/sisaisen-turvallisuuden-strategia (accessed on 13 February 2019).

37. Ministry of Interior of Finland. National Risk Assessment 2018; Ministry of Interior of Finland: Helsinki, Finland, 2019; ISBN 978-952-324-249-4. Available online: https://intermin.fi/julkaisut/julkaisu?pubid=URN: (accessed on 13 February 2019).

38. Government Offices of Sweden. Sweden's Defence Policy 2016 to 2020; Government Offices of Sweden: Stockholm, Sweden, 2015. Available online: https://www.government.se/information-material/2015/06/ swedens-defence-policy-2016-to-2020/ (accessed on 2 March 2019).

39. Swedish Civil Contingencies Agency. A summary of risk areas and scenario analyses 2012-2015. Prepared for the National Risk and Capability Assessment 2016. 2015. Available online: https://www.msb.se/ Upload/Forebyggande/Krisberedskap/MSB1021_Summary-Risk-Areas-Scenario-Analyses.pdf (accessed on 2 March 2019).

40. Government Offices of Sweden. National Security Strategy. Prime Minister's Office, 20 January 2017. Available online: http://www.government.se/4aa5de/contentassets/0e04164d7eed462aa511ab03c890372e/ national-security-strategy.pdf (accessed on 7 February 2018).

41. Ministry of Transport and Communications of Finland. Luonnononnettomuuksien varoitusjärjestelmä (LUOVA). Report 2005. Available online: http://julkaisut.valtioneuvosto.fi/handle/10024/78637 (accessed on 13 February 2019).

42. Swedish Civil Contingencies Agency. Arbetsgrupp naturolyckor-Aktivitetsplan 2019; Swedish Civil Contingencies Agency: KArlstad, Sweden, 2019. Available online: https://www.msb.se/ Upload/Forebyggande/Naturolyckor_klimat/Aktivitetsplan\%20naturolyckor\%202019.pdf (accessed on 13 February 2019).

43. Swedish Meteorological and Hydrological Institute. Myndighetsnätverket för Klimatanpassning. Verksamhetsbeskrivning 2017. Available online: http://www.klimatanpassning.se/polopoly_fs/1.114883! /Verksamhetsbeskrivning\%20Myndighetsn\%C3\%A4tverket\%20f\%C3\%B6r\%20Klimatanpassning.pdf (accessed on 13 February 2019).

44. Prime Minister's Office. Keinot edistää sää-ja ilmastoriskien hallintaa. In Government Report; 2 December 2016. Available online: https:/tietokayttoon.fi/documents/10616/2009122/47_Keinot+edist\%C3\%A4\%C3\%A4+ s\%C3\%A4\%C3\%A4-+ja+ilmastoriskien+hallintaa/2494b562-b446-4884-bc85-0ade9d4b8cf1?version=1.0 (accessed on 22 November 2018).

45. National Emergency Supply Agency. Huoltovarmuuden skenaariot 2030. Report 2018. Available online: https://cdn.huoltovarmuuskeskus.fi/app/uploads/2018/10/23143222/Skenaariot-2030_2p.pdf (accessed on 17 February 2018).

46. Ministry of Economic Affairs and Employment of Finland. Valtioneuvoston päätös huoltovarmuuden tavoitteista. Gov. Decis. 2018, 1048. Available online: https://tem.fi/en/article/-/asset_publisher/ huoltovarmuuden-tavoitteet-lisaa-huomiota-energiansaantiin-digitaalisuuteen-logistiikkaan-jakyberturvallisuuteen (accessed on 17 February 2019).

47. Brink, E. Adapting Cities. Ecosystem-Based Approaches and Citizen Engagement in Municipal Climate Adaptation in Scania, Sweden. Doctoral Dissertation, Faculty of Social Sciences Lund University, Lund, Sweden, 2018. Available online: http://portal.research.lu.se/ws/files/43099365/Brink_2018_Adapting_Cites_ E_spik.pdf (accessed on 13 February 2019).

48. Government Offices of Sweden. Programme for Sweden's Membership of the United Nations Security Council 2017-2018; Ministry for Foreign Affairs, 2016. Available online: https: //www.government.se/4b0225/contentassets/9902f281db8d4eaab5b590c4c9f24a75/programme-forswedens-membership-of-the-united-nations-security-council-20172018.pdf (accessed on 15 February 2019).

49. Planetary Security Initiative. Where the World Stands on Climate Security? A Summary of the UNSC Debate. News Report. 17 July 2018. Available online: https://www.planetarysecurityinitiative.org/news/where-worldstands-climate-security-summary-unsc-debate (accessed on 15 February 2019). 
50. Stockholm Resilience Centre. New Swedish Initiative to Highlight Climate-Security Links. Research News. 30 August 2018. Available online: https://www.stockholmresilience.org/research/research-news/2018-08-30new-swedish-initiative-to-highlight-climate-security-links.html (accessed on 18 October 2018).

51. Hakala, E. Climate Security: Strategy or Necessity for Finland? FIIA Briefing Paper 209; FIIA: Helsinki, Finland, 2016.

52. Ministry for Foreign Affairs of Finland. Development and Security in Finland's Development Policy. Guidelines on Cooperation 2010. Available online: https://julkaisut.um.fi/p/80-development-and-securityin-finlands-development-policy-guidelines-on-cooperation/ (accessed on 16 February 2019).

53. Aaltola, M.; Käpylä, J.; Mikkola, H.; Behr, T. Towards the Geopolitics of Flows. FIIA Report 40. 2016. Available online: https://www.fiia.fi/en/publication/huoltovarmuus-muutoksessa (accessed on 17 February 2019).

54. Lausuntopalvelu. Hallituksen Esitysluonnos Laiksi Hiilen Energiakäytön Kieltämisestä. 2019. Available online: https://www.lausuntopalvelu.fi/FI/Proposal/Participation?proposalId=fade67cc-4fe8-433b-9ff7dd89f1c839d8 (accessed on 26 February 2019).

(C) 2019 by the authors. Licensee MDPI, Basel, Switzerland. This article is an open access article distributed under the terms and conditions of the Creative Commons Attribution (CC BY) license (http://creativecommons.org/licenses/by/4.0/). 